\title{
MODEL-BASED ASSESSMENT OF SPATIAL DISTRIBUTION OF STOMATAL CONDUCTANCE IN FORAGE HERB ECOSYSTEMS
}

\author{
A.V. DOBROKHOTOV', I.L. MAKSENKOVA', L.V. KOZYREVA1, R. SÁNDOR ${ }^{2}$ \\ ${ }^{1}$ Agrophysical Research Institute, Federal Agency of Scientific Organizations, 14, Grazhdanskii prosp., St. Petersburg, \\ 195220 Russia, e-mail dobralexey@gmail.com, ilona_maksenkova@mail.ru, 4ludak@gmail.com (corresponding author); \\ 2 Institute for Soil Sciences and Agricultural, Centre for Agricultural Research, Chemistry Hungarian Academy of Sci- \\ ence, 1022 Hungary, Budapest, Herman Otty str. 15, e-mail sandor.renata@agrar.mta.hu
} ORCID:

Dobrokhotov A.V. orcid.org/0000-0002-9368-6229; Maksenkova I.L. orcid.org/0000-0003-4982-6180;

Kozyreva L.V. orcid.org/0000-0001-7990-8211; The authors declare no conflict of interests Received March 28, 2017 Sándor R. orcid.org/0000-0001-5132-1945

\section{Abstract}

Stomatal conductance is an important factor which controls carbon and water exchange. By changing stomatal width, a canopy simultaneously controls both the carbon dioxide supply and water loss during transpiration. Stomatal conductance is a parameter of photosynthesis and can help to estimate canopy growth and development in ecosystems. Therefore, it is a necessary component of transpiration models. The aim of this study was to validate a stomatal conductance model using radiometric measurements of energy balance parameters for vegetated surfaces: vegetated surface temperature, sensible and latent heat flux. Considering atmospheric surface layer stability, the crop was assumed to be a «big-leaf», with stomatal conductance influenced by environmental factors. External conditions not only control stomata width, but also directly affect the transpiration processes. We have tested the stomatal conductance model by J.M. Blonquist et al. (2009) based on radiometric canopy temperature and energy balance components such as latent and sensible heat fluxes. The applicability of the model for estimating stomatal conductance using automated ground-based measurements and remote sensing was first shown. Observations were carried out at two locations with forage herbs $\left(60^{\circ} 5^{\prime} 6^{\prime \prime} \mathrm{N}, 30^{\circ} 25^{\prime} 27^{\prime \prime} \mathrm{E}\right.$ and $\left.60^{\circ} 5^{\prime} 16^{\prime \prime} \mathrm{N}, 30^{\circ} 24^{\prime} 32^{\prime \prime} \mathrm{E}\right)$ at Bugry in the Leningradskaya Province (on May 15 and 31, 2016, respectively). Model inputs, such as air temperature and humidity, atmospheric pressure, wind speed, radiometric temperature and net radiation of vegetated surface were measured with automatic mobile field agrometeorological equipment AMFAE (Agrophysical Research Institute), with measurements taken every 90 seconds. Ground observations were carried out simultaneously with LandSat- 8 satellite data surveys. LandSat- 8 is an American Earth observation satellite, it contains two instruments: OLI (Operational Land Imager) has 5 visible bands and 4 near infrared bands, TIRS (Thermal InfraRed Sensor) has 2 longwave infrared bands. LandSat- 8 data is freely available on the US Geological Survey. Atmospheric correction of satellite imagery was made using the 6S (Second simulation of the satellite signal in the solar spectrum) open source model with publicly available data of aerosol optical depth at $550 \mathrm{~nm}$ provided by the MODIS system and the global digital elevation model ASTER GDEM (data is freely available on the US Geological Survey). Components of the energy balance including net radiation, soil heat flux, sensible and latent heat flux were calculated with the SEBAL (Surface Energy Balance Algorithm for Land) model by W.G.M. Bastiaanssen (1998) using the ground observation meteorological data from AMFAE. Obtained maps of net radiation and sensible and latent heat fluxes were used to estimate the spatial distribution of stomatal conductance over the forage herbs. For stomatal conductance calculations the LandSat- 8 data for pixel values representing dense vegetation (NDVI > 0.7) were used. As a result of the study, maps of forage herbs stomatal conductance were obtained depending on the canopy temperature and the components of the energy balance with a stratification of the atmosphere boundary layer.

Keywords: stomatal conductance, stomatal resistance, transpiration, energy balance equation, vegetation surface temperature, LandSat-8, automatic mobile field agrometeorological equipment - AMFAE

Plants can change an aperture of stomatal pores quickly to optimize environmentally dependent water loss (transpiration) and $\mathrm{CO}_{2}$ absorption through stomata. The stomatal conductance varies under the influence of numerous fac- 
tors. The transpiration rate is regulated by the stomatal conductance that may be simulated for a leaf or a crop canopy. The state-of-the-art physiological equipment (diffusion porometers, gas analyzers) [1] enables to measure the transpiration and stomatal conductance on a leaf surface. However, it is impossible to estimate the values under study by direct measurements.

As an alternative, models reflecting the stomatal conductance dependence on environmental factors were proposed. Input data here is meteorological and actinometric measurements, and aerodynamic parameters of the underlying surface. Mathematical description of the stomatal conductance has been widely used in recent decades. The review of G. Damour et al. [1] considers 35 similar models. Some models are the most popular in current studies [2-4].

Quantification of $\mathrm{H}_{2} \mathrm{O}$ and $\mathrm{CO}_{2}$ flows in a biogeocenosis under the influence of climatic factors requires both experimental and model-based research methods to be developed. Simulation approaches is a main mechanism for studying the energy and mass exchange and taking into account the spatial heterogeneity and biological peculiarities of plant development during the growing season [5, 6]. A great number of approaches were elaborated to describe flows of $\mathrm{H}_{2} \mathrm{O}$ and $\mathrm{CO}_{2}$ in the soil-vegetation-surface air system. It was shown that stomatal resistance for water vapor and $\mathrm{CO}_{2}$ diffusion depends on a large number of parameters which describe a plant habitat (e.g. solar radiation, air temperature, surface air conditions, wind velocity, $\mathrm{CO}_{2}$ concentration, air humidity and soil moisture deficit, etc.) and status [7-11].

Stomatal regulation of diffusion resistance may be considered as a cybernetic system with different feedbacks [7]. One of them is activated when $\mathrm{CO}_{2}$ partial pressure in intercellular spaces changed; the other one provides a rapid reaction of a stomatal apparatus to relative air humidity fluctuations. Both feedbacks are manifested within a few minutes and control the stomatal conductance at optimal water conditions.

There are several information levels in simulating the water and carbon exchange of plants. The first three levels do not take into account the stomatal regulation, and in this the mass exchange is calculated based on the water potential of soil or determined based on data on water potential of a leaf, solar radiation and other environmental factors. At the fourth level, special models capable of simulating the stomatal apparatus reaction to fluctuating environmental factors are used. By analogy with the Ohm's law, it has been proposed to use resistance $\left(r_{s}\right)$ instead of stomatal conductance $\left(g_{s}\right)(7)$. In the model described by G.S. Campbell et al. (12), the stomatal conductance, heat and water fluxes above the vegetated surface are measured in molar units. The stomatal conductance to resistance relationship is nonlinear and depends on air temperature and atmospheric pressure [13]. Stomatal resistance $\left(r_{s}, \mathrm{~s} \cdot \mathrm{m}^{-1}\right)$ is expressed through stomatal conductance $\left(g_{s}\right)$ and molecular air density $\left(\rho_{m o l}\right.$, mole $\left.\cdot \mathrm{m}^{-2} \cdot \mathrm{s}^{-1}\right)$ as follows:

$$
r_{s}=\frac{\rho_{m o l}}{g_{s}} .
$$

The molecular air density depends on the atmospheric pressure $(P)$ and ambient air temperature $(T)$ [12]:

$$
\rho_{\text {mol }}=44.6 \frac{\mathrm{P}}{101,3} \frac{273,15}{\mathrm{~T}} .
$$

Water vapor fluxes near the vegetated surface by means of turbulent and molecular exchanges. A water vapor flow from a stomatal cavity is defined by the molecular diffusion and, in accordance with the Fick's law, is proportional to 
the local gradient of water vapor density.

In this study, we for the first time have shown the use of a stomatal conductance calculation model [13] based on satellite data on the surface temperature distribution and visible and near infrared reflectance in conjunction with parameters obtained in simultaneous ground truth measurements using the predeveloped automatic mobile field agrometeorological equipment (AMFAE) [5]. As a result, thematic maps of the stomatal conductance spatial distribution on the fields studied have been compiled. In addition, the stomatal conductance at a single point was calculated based on the AMFAE measurements.

The aim of the study was to test techniques for automatic monitoring of stomatal conductance and its spatial distribution based on spaceborne remote sensing data combined with ground-based meteorological measurements with the use of mathematical simulation.

Technique. The stomatal conductance was calculated for forage herbs grown on the fields near Bugry village (Leningrad Region, $60^{\circ} 5^{\prime} 6^{\prime \prime} \mathrm{N}, 30^{\circ} 25^{\prime} 27^{\prime \prime} \mathrm{E}$ ) as of May 15, 2016 and May 31, 2016.

To estimate the stomatal conductance, the model of J.M. Blonquist et al. [13] was selected. It includes automatic ground-based vegetation temperature measurements by infrared thermometers in conjunction with the calculation of radiation balance and components of heat balance. The equation of heat balance above the vegetated surface is as follows:

$$
R_{n c}=H_{c}+\lambda E_{c}+A_{n},
$$

where $R_{n c}$ is the radiation balance above the vegetated surface, $\mathrm{W} \cdot \mathrm{m}^{-2} ; H_{c}$ and $\lambda E_{c}$ are sensible and latent heat fluxes, respectively, $\mathrm{W} \cdot \mathrm{m}^{-2} ; A_{n}$ is carbon dioxide flow, $\mathrm{W} \cdot \mathrm{m}^{-2}$. The carbon dioxide flow in the heat balance is generally ignored (except for cases when its determination constitutes the aim of a study).

Remote sensing data was obtained from American LandSat-8 (freely available on U.S. Geological Survey Site: https://www.usgs.gov/). The satellite is equipped with special instruments: OLI (Operational Land Imager) takes visible (5 channels) and near infrared (4 channels) images, TIRS (Thermal InfraRed Sensor) takes far infrared (thermal) images (2 channels) (14).

The brightness temperature (satellite images) was converted into the true one using an algorithm [15] based on the comparison of data obtained from two LandSat- 8 heat channels and ground surface classification by underlying surface types.

Information about the spatial distribution of radiation balance, total evaporation and turbulent heat flux taking into account the surface air stratification was obtained with the SEBAL (Surface Energy Balance Algorithm for Land) model $[16,17]$ based on the heat balance equation and visible, near infrared (IR) and thermal data of satellite sensing.

Atmospheric correction of the visible and near IR satellite imagery was made using the 6S open source model (Second simulation of the satellite signal in the solar spectrum) [18-20] that described the electromagnetic radiation transmission through the atmosphere. The atmospheric condition parameters required for the calculations (aerosol optical thickness of the atmosphere at $\lambda=550 \mathrm{~nm}$ ) are freely provided in the MODIS system [21] and the global digital elevation model ASTER GDEM [22] allowing for extracting local data (U.S. Geological Survey).

Additional ground-based measurements of the wind velocity at a single point (required for the SEBAL model), as well as the air temperature and humidity, atmospheric pressure (required to insert in the spatial stomatal conductance distribution model) [13] were made simultaneously with satellite observations using the automatic mobile field agrometeorological equipment (AMFAE) (designed at 
Agrophysical Research Institute) [5] fitted with air temperature HEL-705-U-1-12C2, relative air humidity $\mathrm{HIH}-4602-\mathrm{C}$ and atmospheric pressure MPX4115AP sensors (Honeywell International, Inc., USA), as well as wind velocity sensor Windgeschwindigkeitssensor (Hydrometeorologische Instrumente und Messanlagen, Germany) (with meteorological ground truth measurements taken every 90 seconds).

Being a ground-based meteorological station for ground truth measurements, the AMFAE was also used as an independent instrument for automatic monitoring of the stomatal conductance and components of the heat balance at a single point. The AMFAE has an infrared temperature sensor Optris CT LT (Optris GmbH, Germany) and balance meter Peleng SF-08 (OAO Peleng, Republic of Belarus) to determine the vegetated surface temperature and radiation balance based on which the stomatal conductance at a single point was calculated.

The stomatal conductance $g_{s}$ was calculated by the formula of J.M. Blonquist et al. [13]:

$$
g_{S}=\frac{g_{V} P\left[\left(R_{n c}-A_{n}\right)-g_{H} C_{p}\left(T_{c}-T_{a}\right)\right]}{g_{V} \lambda\left(e_{s c}-e_{A}\right)-P\left[\left(R_{n c}-A_{n}\right)-g_{H} C_{p}\left(T_{c}-T_{a}\right)\right]},
$$

where $T_{c}$ is radiometric temperature of the vegetated surface, ${ }^{\circ} \mathrm{C} ; T_{a}$ is air temperature, ${ }^{\circ} \mathrm{C} ; C_{p}$ is specific heat capacity at constant pressure, $\mathrm{J} \cdot \mathrm{kg}^{-1} \cdot \mathrm{K}^{-1} ; \lambda$ is latent heat of vaporization, $\mathrm{MJ} \cdot \mathrm{kg}^{-1} ; e_{s c}$ is water-vapor saturation pressure at the vegetation temperature $T_{c}, \mathrm{kPa} ; e_{a}$ is partial water vapor pressure, $\mathrm{kPa} ; P$ is atmospheric pressure, $\mathrm{kPa} ; g_{H}$ is heat conductivity in the surface air, mole $\cdot \mathrm{m}^{-2} \cdot \mathrm{s}^{-1} ; g_{V}$ is water vapor conductivity in the surface air, mole $\cdot \mathrm{m}^{-2} \cdot \mathrm{s}^{-1}$.

The heat conductivity $\left(g_{H}\right)$ in the surface air where flows were not affected by molecular viscosity were calculated taking into account the underlying surface roughness [5]. The lower and upper levels of the layer depend on roughness parameters for a flux of momentum $\left(z_{m}\right)$, heat flux $\left(z_{h}\right)$ and water vapor flux $\left(z_{v}\right)$ over the displacement layer $(d)$ [23]:

$$
g_{H}=\frac{u \rho_{m o l} k^{2}}{\left[\ln \left(z_{u}-d / z_{m}\right)-\Psi_{m}\right]\left[\ln \left(z_{T a}-d / z_{h}\right)-\Psi_{h}\right]} .
$$

The roughness parameters may be defined as $d=0.65 h_{c}, z_{m}=0.123 h_{c}$, $z_{h} 0.1 z_{m}, z_{v} \approx z_{h} ; z_{u}$ and $z_{T a}$ are levels of air velocity and temperature measurements, respectively; $h_{c}$ is canopy height; $k$ is Karman constant; $u$ is wind current velocity at the level of $z_{u} ; \Psi_{m}, \Psi_{h}$ are universal functions for the flux of momentum and heat flux [23-25].

The water vapor conductivity in the canopy layer $g_{V}$ is calculated similarly to $g_{H}$ by formula (5) using the corresponding parameters.

Results. The stomatal conductance $g_{s}$ values obtained in the first determination (on May 15) based on the model [13] using the automatic mobile field agrometeorological equipment (AMFAE) when measuring the vegetated surface temperature and radiation balance at a single point generally were lower than those obtained in the second determination (on May 31) (Fig. 1).

The observed result can be explained by that, on May 31, the vegetated surface temperature under similar meteorological conditions was lower than the air temperature, there was an oasis effect, and the turbulent heat flux was directed towards the vegetated surface. When measuring on May 15, the surface temperature exceeded the air temperature and, therefore, the radiation balance reflected not only transpiration and photosynthesis, but also the turbulent heat flux from the vegetated surface. 


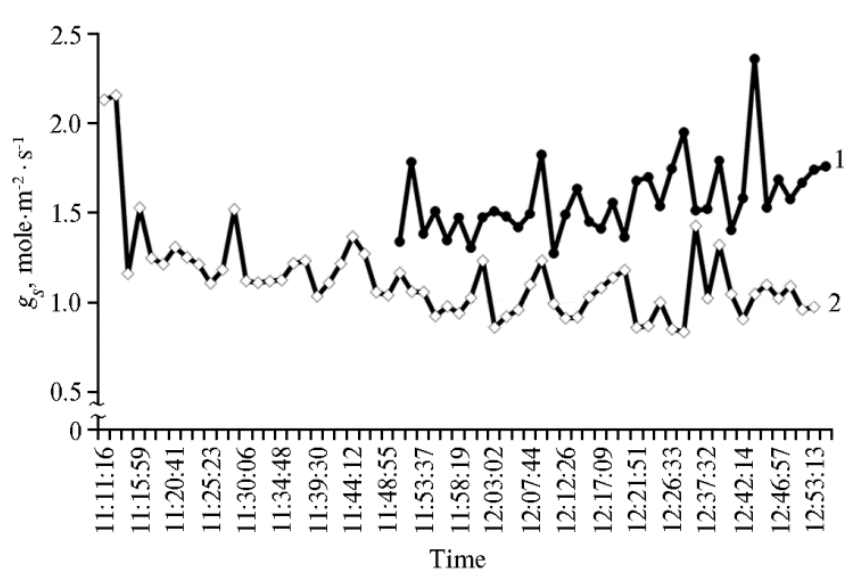

Fig. 1. Estimates of stomatal conductance $\left(g_{s}\right)$ in forage herbs calculated by the model of J.M. Blonquist et al. [13] based on agrometeorological measurements: 1 and $2-$ registration of meteorological data on May 15 $\left(60^{\circ} 5^{\prime} 6^{\prime \prime} \mathrm{N}, 30^{\circ} 25^{\prime} 27^{\prime \prime} \mathrm{E}\right)$ and May $31\left(60^{\circ} 5^{\prime} 16^{\prime \prime} \mathrm{N}, 30^{\circ} 24^{\prime} 32^{\prime \prime} \mathrm{E}\right)$ (Bugry village, Leningrad Oblast, 2016). The measurements were made using the automatic mobile field agrometeorological equipment (AMFAE) [5].

Having processed the remote sensing and ground truth monitoring data after the atmospheric correction of LandSat-8 satellite imagery using the $6 \mathrm{~S}$ model [18-20], we have obtained the visible (5 channels) and near IR (4 channels) reflectance values which were used to calculate the radiation and aerodynamic characteristics of vegetation by the SEBAL model. Then, we have calculated the true surface temperature using the algorithm proposed by $\mathrm{C}$. Du et al. [15] in order to insert it in the formula for calculating the stomatal conductance by the model applied [13].

The satellite image classification by types of the underlying surface, NDVI (Normalized Difference Vegetation Index), and ground-based measurements of wind velocity made it possible to calculate the spatial distribution of roughness parameters for the heat and momentum fluxes which were required for the turbulent heat flux estimation. To assess the spatial distribution of the stomatal conductance, the thematic maps have been compiled for all the heat balance components calculated by the SEBAL model taking into account ground-based meteorological measurements using the AMFAE system.

A
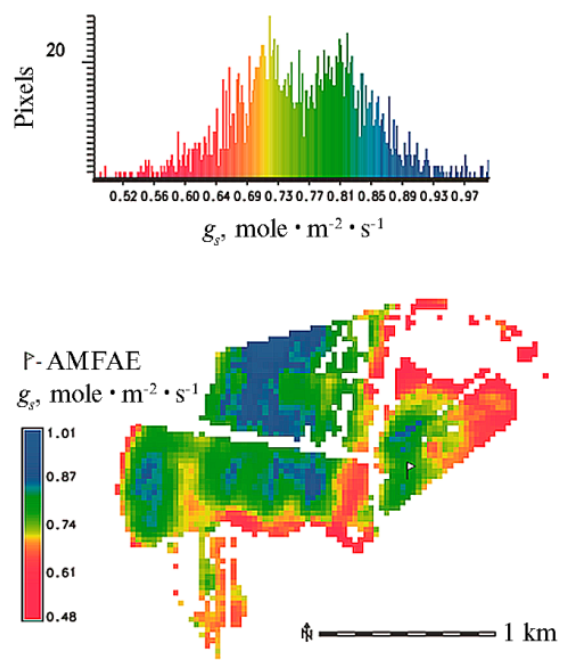

B
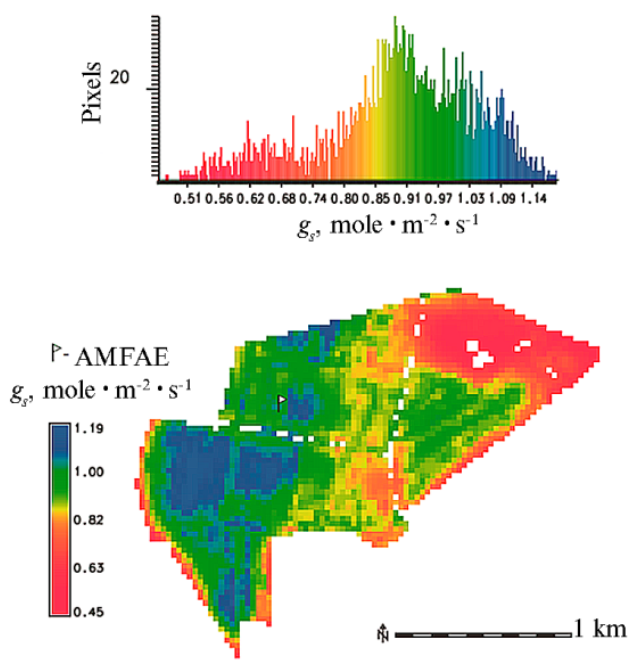

Fig. 2. Spatial distribution of the stomatal conductance $\left(g_{s}\right)$ in forage herbs when estimating by the model of J.M. Blonquist et al. [13] in conjunction with the SEBAL model [17] and LandSat-8 (USA) images [14]: A and B - on May 15 and May 31, 2016, respectively; upper line - bargraph of conductance values, lower line - pixel characteristics of images (Bugry village, Leningrad Oblast, 2016). A flag designates the place of ground-based registration of data by the automatic mobile field agrometeorological equipment (AMFAE) [5] (May $15-60^{\circ} 5^{\prime} 6^{\prime \prime} \mathrm{N}$, 
$30^{\circ} 25^{\prime} 27^{\prime \prime} \mathrm{E}$; May $\left.31-60^{\circ} 5^{\prime} 16^{\prime \prime} \mathrm{N}, 30^{\circ} 24^{\prime} 32^{\prime \prime} \mathrm{E}\right)$. Scale is $1 \mathrm{~km}$.

As a result, based on the satellite data (the satellite transit time is about $12^{04}$ ) and results of ground-based measurements, thematic maps and bargraphs of the stomatal conductance $g_{s}$ have been constructed (Fig. 2). On average, the stomatal conductance values (like in determining at a single point) on May 15 were lower than those on May 31. In the high stomatal conductance areas, $g_{s}$ values were approximately twice as much as those in the low stomatal conductance areas.

Thus, it was shown that the tested model could be applied for the automatic monitoring of spatial distribution of the stomatal conductance in plants using data of radiometric measurement of the vegetated surface temperature, model calculation of components of the underlying surface heat balance obtained by the remote sensing in conjunction with simultaneous ground-based measurements of air temperature and humidity, atmospheric pressure and wind current velocity. To improve the stomatal conductance accuracy, the highly sensitive measurement of the true temperature of the canopy taking into account its radiation capacity is required, and the use of the high-precision atmospheric correction of the satellite channels is also necessary to obtain true ground parameters not affected by atmosphere.

\section{REFERENCES}

1. Damour G., Simonneau T., Cochard H., Urban L. An overview of models of stomatal conductance at leaf level. Plant, Cell \& Environment, 2010, 33: 1419-1438 (doi: 10.1111/j.1365-3040.2010.02181.x).

2. Ga o Q., Zhao P., Z eng X., Cai X., She n W. A model of stomatal conductance to quantify the relationship between leaf transpiration, microclimate and soil water stress. Plant, Cell \& Environment, 2002, 25(11): 1373-1381 (doi: 10.1046/j.1365-3040.2002.00926.x).

3. Lu P., Yunus a I.A., Wa lker R.R., M ü 11 e r W.J. Regulation of canopy conductance and transpiration and their modelling in irrigated grapevines. Functional Plant Biology, 2003, 30(6): 689-698 (doi: 10.1071/FP02181).

4. Li u F., Anders e n M.N., J e n s e n C.R. Capability of the 'Ball-Berry' model for predicting stomatal conductance and water use efficiency of potato leaves under different irrigation regimes. Scientia Horticulturae, 2009, 122(3): 346-354 (doi: 10.1016/j.scienta.2009.05.026).

5. Kozyreva L.V., Dobrokhotov A.V., Sitdikova Yu.R., Efimov A.E. Metodika otsenki sostavlyayushchikh vodnogo i teplovogo balansov $v$ sisteme "pochva-rastenie-prizem-nyi sloi vozdukha» $s$ uchetom stratifikatsii prizemnogo sloya, neodnorodnosti podstilayushchei poverkhnosti $s$ ispol'zovaniem dannykh distantsionnogo zondirovaniya zemli i nazemnoi kalibrovki avtomatizirovannym mobil'nym polevym kompleksom (AMPAK) [Estimation of water and heat balance in soil-plant- air with regard to surface air stratification and soil surface heterogeneity as based on satellite data and measurements with automatic mobile field agrometeorological equipment, AMFAE]. St. Petersburg, 2016 (in Russ.).

6. Alle n R.G., T as u mi M., Trezza R. Satellite-based energy balance for mapping evapotranspiration with internalized calibration METRIC)-Model. J. Irrig. Drain. E-ASCE, 2007, 133(4): 380-394 (doi: 10.1061/(ASCE)0733-9437(2007)133:4(380)).

7. Si rote n k o O.D. Osnovy sel'skokhozyaistvennoi meteorologii. Tom II. Metody raschetov $i$ prognozov v agrometeorologii. Kniga 1. Matematicheskie modeli v agrometeorologii [Fundamentals of agricultural meteorology. V. II. Calculation and prediction. Book 1. Mathematical models]. Obninsk, 2012 (in Russ.).

8. Steduto P., Hsia o T.C., Ra es D., Fereres E. AquaCrop - The FAO crop model to simulate yield response to water: I. Concepts and underlying principles. Agronomy Journal, 2009, 101(3): 426-437 (doi: 10.2134/agronj2008.0139s).

9. Raes D., Stedut o P., Hsiao T. C., Fereres E. AquaCrop the FAO crop model to simulate yield response to water: II. Main algorithms and software description. Agronomy Journal, 2009, 101(3): 438-447 (doi: 10.2134/agronj2008.0140s).

10. Polue k tov R.A., O pari n I.V., T e r l e e v V.V. Meteorologiya i gidrologiya, 2003, 11: 90-98 (in Russ.).

11. Perez P.J., Lecina S., Castel1vi F., Martínez-Cob A., Villa lobos F.J. A simple parameterization of bulk canopy resistance from climatic variables for estimating hourly evapotranspiration. Hydrol. Process., 2006, 20(3): 515-532 (doi: 10.1002/hyp.5919).

12. Campbe 11 G.S., Norman J. M. An introduction to environmental biophysics. Springer- 
Verlag, NY, 1998 (doi: 10.1007/978-1-4612-1626-1).

13. Blonquist J.M., Norman J.M., Bugbee B. Automated measurement of canopy stomatal conductance based on infrared temperature. Agr. Forest Meteorol., 2009, 149(12): 21832197 (doi: 10.1016/j.agrformet.2009.10.003).

14. Roy D.P., Wuld e r M.A., L o veland T.R., Wo o d c o c k C.E., Alle n R.G. Landsat8: Science and product vision for terrestrial global change research. Remote Sens. Environ., 2014, 145: 154-172 (doi: 10.1016/j.rse.2014.02.001).

15. Du C., Re n H., Q in Q., M e ng J., Z h a o S. A practical split-window algorithm for estimating land surface temperature from Landsat 8 data. Remote Sens., 2015, 7(1): 647-665 (doi: $10.3390 / \mathrm{rs} 70100647)$.

16. B a st i a a s s e n W.G.M., Noordman E.J.M., P elgrum H., Davids G., Thor e s o n B.P., A $11 \mathrm{e}$ n R.G. SEBAL model with remotely sensed data to improve waterresources management under actual field conditions. J. Irrig. Drain. E-ASCE, 2005, 131(1): 8593 (doi: 10.1061/(ASCE)0733-9437(2005)131:1(85)).

17. Alle n R.G., Tas umi M., Trezza R., Waters R., B astia a s se n W. $S E B A L$ (Surface Energy Balance Algorithms for Land). Advance Training and Users Manual. Idaho Implementation, 2002, V. 1.

18. Vermote E.F., Ta n ré D., D e u ze J.L., Herman M., M o r c e t t e J.J. Second simulation of the satellite signal in the solar spectrum, 6S: An overview. IEEE Transactions on Geoscience and Remote Sensing, 1997, 35(3): 675-686 (doi: 10.1109/36.581987).

19. Kotchenova S.Y., Vermote E.F., Mat a r rese R., K le m m F.J., Jr. Validation of a vector version of the $6 \mathrm{~S}$ radiative transfer code for atmospheric correction of satellite data. Part I: Path radiance. Appl. Optics, 2006, 45(26): 6762-6774 (doi: 10.1364/AO.45.006762).

20. Kotchenova S.Y., Vermote E.F. Validation of a vector version of the $6 \mathrm{~S}$ radiative transfer code for atmospheric correction of satellite data. Part II. Homogeneous Lambertian and anisotropic surfaces. Appl. Optics, 2007, 46(20): 4455-4464 (doi: 10.1364/AO.46.004455).

21. Re me r L.A., K a u f man Y.J., T a n ré D., Mat to o S., Chu D.A., Martins J.V., Li R.R., I chok u C., Le vy R.C., Kle id m a n R.G., Eck T.F., Ve r mote E., Hol b e n B.N. The MODIS aerosol algorithm, products, and validation. J. Atmos. Sci., 2005, 62(4): 947-973 (doi: 10.1175/JAS3385.1).

22. Tachikawa T., Hato M., Kaku M., I was a i A. Characteristics of ASTER GDEM version 2. Proc. 2011 IEEE International Geoscience and Remote Sensing Symposium. Vancouver, BC, 2011: 3657-3660 (doi: 10.1109/IGARSS.2011.6050017).

23. Alle n R.G., Pruitt W.O., Wright J.L., Howe 11 T.A., Ventura F., Snyder R., $\mathrm{S} \mathrm{mith} \mathrm{M.} \mathrm{A} \mathrm{recommendation} \mathrm{on} \mathrm{standardized} \mathrm{surface} \mathrm{resistance} \mathrm{for} \mathrm{hourly} \mathrm{calculation} \mathrm{of} \mathrm{ref-}$ erence ETo by the FAO56 Penman-Monteith method. Agr. Water Manage., 2006, 81(1): 1-22 (doi: 10.1016/j.agwat.2005.03.007).

24. Z Ziliti $\mathrm{nk}$ e vi c h S.C. Atmosfernaya turbulentnost' $i$ planetarnye pogranichnye sloi [Atmospheric turbulence and planetary boundary layers]. Moscow, 2013 (in Russ.).

25. $\mathrm{Pag}$ o w s ki M. An iterative solution of flux-profile relationships in the surface layer for regional model applications. Atmos. Environ., 2006, 40(35): 6892-6897 (doi: 10.1016/j.atmosenv.2006.07.027). 